Radka Redlichová*

Gabriela Chmelíková*

Ivana Blažková***

Vojtěch Tamášs****
JEL Classification O1, R1, R3

Preliminary statement

https://doi.org/10.32910/ep.70.6.2

\title{
ROLE OF COMPANIES' SIZE IN SOCIO-ECONOMIC DEVELOPMENT OF REGIONS IN THE CZECH REPUBLIC
}

The aim of this paper is to investigate socio-economic development drivers of NUTS 3 regions in the Czech Republic. The aim is fulfilled by examination of the relationship between one of the regional development factors - the companies' size structure and the development of the region from both socio and economic views. We derive from the theory of diversification and prior empirical findings, and empirically test the role of companies' size in regional development. We use a balanced dataset of 14 regions covering the years 2000 - 2016 that provides the information about regions' socio-economic performance in terms of GDP and unemployment rate. We hypothesise that unemployment rate in the regions with higher share of small firms is less sensitive to the general trend of the whole economy. However, the higher share of small firms leads to improved regional GDP. Our findings confirm that small firms accelerate economic growth while playing a role of

* R. Redlichová, associate professor, Faculty of Regional Development and International Studies, Mendel University in Brno (e-mail: radka.redlichova@mendelu.cz).

${ }^{*}$ G. Chmelíková, associate professor, Faculty of Regional Development and International Studies, Mendel University in Brno (e-mail: chmelikova.gabriela@seznam.cz).

${ }^{* * *}$ I. Blažková, associate professor, Faculty of Regional Development and International Studies, Mendel University in Brno (e-mail: blazkova@mendelu.cz).

${ }^{* * *}$ V. Tamáš, associate professor, Faculty of Regional Development and International Studies, Mendel University in Brno (e-mail: vojtech.tamas@mendelu.cz). The paper was received on July 9th, 2018. It was accepted for publication on December 19th, 2018. 
a social stabiliser in Czech regions. Our conclusions could help in designing the regional policy in the Czech Republic.

Keywords: Average wage, diversification, GDP, regional development, size of companies, unemployment

\section{Introduction}

Identifying the factors involving regional development is a widely spread research problem addressed from the beginning of the regional sciences formation. Different authors have attempted to identify different factors of regional development and their importance, some of whom also suggested models aiming to present the relation between these factors and the development of a region. (e.g. Ullman, 1954; Hoselitz, 1957; Hansen, 1966; Glasmeier, 1988; Hansen, 1990; Florida, Mellander and Stolarick, 2008; Kraftová, 2008; Viturka, 2010; Muñoz and Trombetta, 2015). They concluded that the most important drivers of regional development are geographic location and hard infrastructure, political environment, public administration, technology, and availability of labour force with convenient education and skills. Last but not least, the development is also affected by the ability to attract new investors and by the ability of a positive presentation of the region itself (Coughlin and Segev, 2000; Cheng and Kwan, 2000; Pike, Rodrígues-Pose and Tomaney, 2011; Kramin et al., 2014). Another important factor encouraging regional development in many aspects is the localisation of the companies in the region and their economic activity (e.g. Moore, Tyler and Elliot, 1991; Fritsch and Weyh, 2006; Acs, 2007; Acs and Mueller, 2008; Mateo, Solves and Gras, 2013; Haltiwanger, Jarmin and Miranda, 2013). In this respect, a lot of attention is paid to the formation of new enterprises (e.g. Fritsch and Mueller, 2008; van Stel and Suddle, 2008; Baptista, Escária and Madruga, 2008; Arias, Atienza and Cademartori, 2014). The importance of this factor is encouraged by worldwide support not only of domestic companies (in particular small and medium ones), but also of foreign direct investment.

In recent years, the factor of firm size has become an object of empirical studies evaluating the drivers of economy on the national basis. Based on the findings of these studies, small firms are seen as providing the energy for economic growth (Horell and Litan, 2010). Fast growing economies usually have a larger number of small companies than stagnating economies. The role of small companies in an economy has several dimensions. One of the most important attributes of their relationship to the socio-economic system is the creation of new jobs (Kane, 2010). However, empirical evidence on the role of size in regional context is rare. 
The impact of the size structure as a specific factor on the regional development is not very often a topic in the regionalist publications. Most of the authors, as mentioned above, are looking for the "regional development formula", focused on the business environment or regional competitiveness as the main factors connected with the companies' localization. The relation between regional development and companies is studied mainly as an impact of business environment to SME development. The opposite relationship is not studied so often (e.g. Glasmeier, 1988; Brown et al., 1990; Văduva, 2008; Agyapong, 2010; Cravo, 2010; Damborský and Wokoun, 2010; Wang et al., 2010; De Jorge and Suarez, 2011; Ouedraogo, 2012; Foreman-Peck and Tom al., 2013; Blažková and Chmelíková, 2016).

A study dealing with the impact of the companies localized in the region on the regional development was carried out by Guzmán et al., 2014, who researched this relation in six Spanish regions. However, the authors were mainly focused on the tightness of the companies' relations, not primly on their size. The mutual relations (input-output analysis) as well as the size structure in six regions (as well in Spain), was the research topic of Romero and Francisco, 2007.

The most widely used segmentation of companies according to their size is into micro, small, medium and large ones. This segmentation is usually based on the total number of employees and / or on the volume of the annual turnover. Each size category has its advantages and disadvantages. One of the main advantages of small and medium enterprises (SME) is the reaction time to some change. The change in range of products or in strategy is easier and faster compared to the large companies. Besides the economic criterion, the closer social relationship among the employees or between the employees and the employer could be the advantage of a SME, as well as stronger staff loyalty. On the other hand, a SME cannot benefit from economies of scale and could have a problem to find additional financial resources, if necessary. (e.g. Boswell, 2014; Sahut and Peris-Ortiz, 2014; Roberts, 2014; Ibrahim, 2015; Gilinsky Jr et al., 2015). The larger the company is and the more specialized it is, the higher economies of scale are. Another advantage of economies of scale is the possibility of better resources usage as by-products production or further manufacture of waste. The impact of large companies on regional development is faster and more significant than in the case of SME. If there are more successful large companies in the region, the regional GDP can be substantially involved. However, if these companies end their business, the impact on unemployment increase is crucial as well. It is mainly the regions with highly specialized companies that are at risk. For the dismissed employees it is more complicated to find another job, because of their narrow qualification and specialization. (Nooteboom, 1993; Agrawal et al., 2014; Vandaie and Zaheer, 2014; Goffee and Scase, 2015).

The article is therefore focused on the research gap of missing evidence on the role of business size in regional development. We draw on the findings from 
the evidence on the national levels and the theory of diversification. These lead us to the hypothesis that unemployment rate in the regions with higher share of small firms is less sensitive to changes in the performance of the economy; however, the higher share of small firms leads to improved GDP. Our findings confirm that small firms accelerate the economic growth while playing the role of a social stabiliser in the Czech region.

The remainder of our paper proceeds as follows: drawing from the literature overview, we develop our hypotheses in the second part, and describe the datasets and methods used in the third part. A simple multivariate OLS regression is applied in the empirical study in the fourth part to identify that small firms accelerate the economic growth and stabilize the employment in the Czech regions. We conclude with a discussion of the main results and implications for policy makers.

\section{Data, Hypotheses and Methods}

\section{Data}

Data from 14 regions in the Czech Republic were used for the analysis, in the time series 2000 - 2016. The independent variable was given by the numbers of companies in the particular size groups (small, medium and large, or, as the case may be, small and others) in these regions.

Real GDP and unemployment data of the same time and spatial series were used for dependent variables. To be able to express these data in a relative way (compared to the Czech Republic), we also needed these for the central level, e.g. for the Czech Republic as a whole.

All the above mentioned data were gathered from the Czech Statistical Office (CSO). As the CSO provides nominal GDP, the World Bank GDP deflator for the base year 2010 was used to calculate real GDP.

The whole time series therefore consists of 16 years and the spatial series of 14 regions. However, the GDP as well as unemployment variable were necessary to be expressed not as absolute value, but rather as year-to-year changes, so that the final data set consists of 210 observation (e.g. 15 time periods (2001 - 2016 changes) and 14 region). 
R. REDLICHOVÁ, G. CHMELÍKOVÁ, I. BLAŽKOVÁ, V. TAMÁŠ: Role of companies' size in socio-economic... EKONOMSKI PREGLED, 70 (6) 833-848 (2019)

\section{Hypothesis}

The aim of the research is to analyse the relationship between one of the regional development factors - the companies' size structure and the development of the region from both socio and economic views. Based on the results, the simultaneous aim is to identify which of the companies (micro, small, medium and large) should be supported to be localized in the region in order to enhance its development.

The criteria for the inclusion of the company to a certain size structure group are set by the Commission Regulation No 800/2008. Appendix I categorizes the company to a certain size group according to the number of employees, volume of annual turnover and balance sheet sum. Differentiation based on the number of employees is used for this purpose by the Czech Statistical Office. Micro companies are defined as companies with a number of employees 1-9, small companies 10-49, medium ones 50-249 and large ones more than 250. For the purpose of this research, companies without employees were included into the first size group of micro companies. This group therefore consists of companies with 0-9 employees.

Not all the factors influencing regional development could be expressed by numbers because of its qualitative character. Nor could all variables describing the development be measured (quality of life, level of satisfaction, level of utility, health condition, and so on). However, for the purpose of this articles' aim, the quantitative data are necessary to be able to express the mutual relation. Standard variable used for the measurement of the level of the region is GDP (gross domestic product). Even if the GDP measures the growth of the region, not its development, as growth is the core part of development, observing GDP trends could be regarded as a relevant way of measuring the influence of companies (meant by sizes) on the economic development / growth of the region (Solow, 1956; Grossman and Helpman 1994).

The variable related to GDP is the unemployment rate. A very strong negative correlation exists between GDP and unemployment rate. This negative dependence is based on Okun's law (e.g. Prachowny, 1993).

This law says that if the GDP is growing, unemployment is going down. Okun's law was examined by many experts (e.g. Savulea, 2008; Haririan et al., 2010; Kitov and Kitov, 2012; Khan et al., 2013; Salman and Shukur, 2014; Kim et al., 2015). When GDP is growing, demand for labour is growing too. When employment rate is growing, the production is growing as well. Besides the economic aspect, the unemployment rate also shows the "social status" in the region. A high rate of employment leads to a better economic situation of the residents and a better inclusion of individuals to the society. The unemployment rate can therefore be regarded as the index of the social status of the region. 
Based on the above discussion, we empirically investigate our overarching research question: to what extent is the size structure of the companies in the region linked to different levels of socio-economic development? From the perceiving discussion we believe that a higher share of small firms in the economy base of the region leads to a higher diversification of labour forces and stabilize the rate of unemployment in the region. In case a small firm enters a bankruptcy process, job cuts are lower than in the case of a large one. On the other hand, the high share of small firms in the economy base creates a higher innovation potential. That is why we hypothesise that high share of small firms accelerates the economic growth. To research these conjectures, we develop the following hypothesis with respect to two particular areas of our interest - Unemployment and GDP growth. Based on Okun's law we assume that unemployment and GDP develop contradictorily; however, the higher proportion of small firms in the region will lead to smaller changes in the unemployment rate and then in the GDP growth:

\section{H1: The smaller the firms in the region, the lower change in the unemploy- ment rate of the region in comparison to the whole economy}

To test the first hypothesis, we take the standard and the most widely accepted measure of societal aspect of regional development - unemployment rate. We calculate the differences of unemployment rate growth in a particular region and the unemployment rate in the whole economy of the Czech Republic. This regional deviation represents our dependent variable for the first hypothesis. Our independent variable is represented by the share of small firms (0-9 employees) in the total number of the firms in the region. We calculate our variables according to the following formulas:

Independent variable:

UNEMP_FLUC $C_{i t}=/$ Unemployment rate growth in $C R_{t} /$ - /Unemployment rate growth in the region I $^{\prime}$

where $t$ stands for the year (2001 - 2016) and $i$ represents the particular regions.

Dependent variable:

SMALL_FIRMS ${ }_{i t}=$ Number of small firms $(0-9 \mathrm{E})$ in the region ${ }_{i t} /$ Number of all firms in the region

where $t$ stands for the year $(2001$ - 2016) and $i$ represents the particular regions.

We believe that the higher the share of small firms in the economic base of the region is, the less volatile the development of unemployment rate in comparison to the whole economy is. E.g. if the unemployment rate in the economy grows between two years by $5 \%$ and in the region $i$ only by $2 \%$, then our independent 
R. REDLICHOVÁ, G. CHMELÍKOVÁ, I. BLAŽKOVÁ, V. TAMÁŠ: Role of companies' size in socio-economic...

EKONOMSKI PREGLED, 70 (6) 833-848 (2019)

variable is $3 \%$. The higher our independent variable is, the less volatile the unemployment rate in the particular region $i$ is.

\section{H2: The smaller the firms in the region, the higher the change in the GDP growth of the region in comparison to the whole economy}

To test the second hypothesis, we take the standard and the most widely accepted measure of the economic aspect of regional development - real GDP growth (we use deflator with 2010 base year). We calculate the differences between the GDP growth in a particular region and the GDP growth in the whole economy of the Czech Republic. This regional deviation of the GDP represents our dependent variable for the second hypothesis. Our independent variable is represented by the share of small firms (0-9 employees) in the economic base of the region. We calculate our variables according to the following formulas:

Independent variable:

$G D P_{-} F L U C_{i t}=/ G D P$ growth in $C R_{t} /-/ G D P$ growth in the region ${ }_{i t}$

where $t$ stands for the year (2001 - 2016) and $i$ represents the particular regions.

Dependent variable:

SMALL_FIRMS $S_{i t}=$ Number of small firms $(0-9 \mathrm{E})$ in the region ${ }_{i t} /$ Number of all firms in the region

where $t$ stands for the year (2001 - 2016) and $i$ represents the particular regions.

We believe that the higher the share of small firms in the economic base of the region is, the more volatile the development of the GDP in comparison to the whole economy is, as the small firms serve as an economic accelerator. E.g. if the GDP in the economy grows between two years by $5 \%$ and in the region $i$ by $7 \%$, then our independent variable is minus $2 \%$. The lower our independent variable is, the less volatile the GDP in the particular region $i$ is.

\section{Methods}

Our data consist of a panel of fourteen regions in the Czech Republic in the period between the years 2000 and 2016, therefore we employ the panel regression analysis. All estimates are made in the software Gretl. We estimated the models with the fixed effects (based on the results of the Hausman test) with robust standard errors, which are consistent against the consequences of autocorrelation and 
heteroscedasticity. Stationarity of variables was proved with the use of the unit root test Levin, Lin \& Chu for the panel data (Levin et al., 2002) and the descriptive statistics for particular variables are presented in Table 1.

\section{Table 1}

\section{DESCRIPTIVE STATISTICS}

\begin{tabular}{|l|r|r|r|r|r|c|}
\hline \multicolumn{1}{|c|}{ Variable } & \multicolumn{1}{c|}{ Mean } & \multicolumn{1}{c|}{ Median } & \multicolumn{1}{c|}{ Max. } & \multicolumn{1}{c|}{ Min. } & \multicolumn{1}{c|}{ Std. Dev. } & Obs. \\
\hline SMALL_FIRMS & 97.650 & 97.639 & 98.401 & 97.015 & 0.3513 & 224 \\
\hline UNEMP_FLUC & -0.00398 & 0.01047 & 0.40844 & -0.42826 & 0.10815 & 224 \\
\hline GDP_FLUC & 0.02196 & 0.02085 & 0.068535 & -0.05311 & 0.02145 & 224 \\
\hline
\end{tabular}

Source: Gretl; authors' elaboration

\section{Results}

Table 2 shows the results based on the estimation of the impact of the firms' size on the fluctuation of the unemployment rate and the fluctuation in economic growth. In a nutshell, the results show that small firms mitigate the trends in the unemployment development and at the same time they accelerate the economic growth.

Table 2

MODEL TABLE

\begin{tabular}{|l|c|c|}
\hline & \multicolumn{2}{|c|}{ Dependent Variables } \\
\hline Independent Variables & UNEMP_FLUC & GDP_FLUC \\
\hline \multirow{2}{*}{ SMALL_FIRMS } & $\mathbf{0 . 4 2 0 7 *}$ & $\mathbf{- 5 . 4 2 3 1 * * *}$ \\
\cline { 2 - 3 } & $(0.0751)$ & $(0.0000)$ \\
\hline \multirow{2}{*}{ CONSTANT } & $\mathbf{9 7 . 6 5 1 9 * * *}$ & $\mathbf{9 7 . 7 6 9 3 * * *}$ \\
\hline R-squared & $(0.0000)$ & $(0.0000)$ \\
\hline Observations & 0.3526 & 0.4204 \\
\hline $\begin{array}{l}\text { Note: } * * * \text { statistical significance at } 1 \% \text { level, ** statistical significance at 5\% level, * } \\
\text { statistical significance at } 10 \% \text { level. Standard Errors are in parenthesis. }\end{array}$ \\
\hline
\end{tabular}

Source: Gretl; authors elaboration 
The results support our first hypothesis that the smaller the firms in the region are, the lower the change in the unemployment rate of the region in comparison to the whole economy is. The changes of the unemployment rate in particular regions always had the same direction as the changes in the whole Czech Republic; however, we find a significant negative relationship between the firms' size and the fluctuation of the unemployment rate. The positive sign of our dependent variable UNEMP_FLUC in Table 2 means that the high share of small firms in the region is significantly associated with high differences from the national average. The higher the differences from the national average are, the less volatile the development in the given region is. In those regions with a higher share of small firms, the change in the unemployment rate is smaller than in the regions with a lower share of small firms. This result supports the idea that diversification of labour forces into more economic entities decreases the riskiness of the whole job portfolio in the region. If the whole economy suffers from recession, the impact of this negative economic development is less intensive in the regions with a higher share of small firms.

These findings are consistent with the research focused on the behaviour of individual firms assessing how changes in employment and regional growth occur (e.g. Birch, 1979), with the contribution of small firms to employment, job creation, and the growth of economy (e.g. Ayyagari et al., 2011). Our empirical results further support the general theory of diversification (Fisher, 1961, Samuelson, 1975, Constantinides and Malliaris, 1995, Markowitz, 1999; Carroll and Keely, 2009). Our findings suggest that the benefits of diversification are statistically significant also in the field of regional dispersion of economic activities. The higher the distribution of labour forces among firms, the less sensitive the changes in the unemployment rate to the general development of the economy.

Our second hypothesis, i.e. the smaller the firms in the region, the higher the change in the GDP growth of the region in comparison to the whole economy, is examined in our second model. Our second hypothesis is supported by a significant positive relationship between the firms' size and the fluctuation of the GDP growth. The negative sign of our dependent variable GDP_FLUC in Table 2 means that a high share of small firms in the region is significantly associated with low differences from the national average. The higher the differences from the national average, the more volatile the development in the given region is. This result supports the idea that a high share of small firms accelerates the economic growth.

\section{Conclusion}

One of the main challenges for Czech policy makers with regard to regional development is to support institutional frameworks of firms' organization that 
enable to secure double bottom line of the development - sustainable social and economic growth. The objective of this article was to analyse whether the size of companies influences regional development. Two indicators have been selected to characterise regional development: GDP as the main indicator of economic growth and unemployment rate as the indicator of social level. Generally, our empirical results support our hypotheses that unemployment rate in the regions with higher share of small firms is less sensitive to the general trend of the whole economy and that a higher share of small firms leads to improved regional GDP. Our findings confirm that small firms accelerate the economic growth while playing a role of a social stabiliser in the Czech regions. The results of our research indicate that small firms mitigate trends in unemployment development and at the same time they accelerate the economic growth.

Our main focus has been on the role that small firms play in regional development in the Czech Republic. We contribute to the body of theoretical and empirical research. Our findings are consistent with the fact that fast growing economies usually have a larger number of small companies than stagnating economies. The role of small companies in an economy has several dimensions. One of the most important attributes of their relationship to the socio-economic system is the creation of new jobs (Kane, 2010). Our empirical results indicate that regions with a higher share of small firms outperform the regions with larger firms in the season of general economic expansion and at the same time they contribute less to the job destruction during economic recession.

Our empirical results further support the general theory of diversification as we found that the higher the distribution of labour forces among firms, the less sensitive the changes in the unemployment rate to the general development of the economy. This result supports the idea that diversification of labour forces into more economic entities decreases the riskiness of the whole job portfolio in the region. If the whole economy suffers from recession, the impact of this negative economic development is less intensive in the regions with a higher share of small firms.

Our main recommendation for an institutional framework of an entrepreneurial environment is to support the genesis of new firms with diversified output portfolio. It seems beneficial to strengthen the diversification of employment by forming conditions needed for establishment and development of small businesses. The influence of the number of small businesses on the employment development is favourable especially in a period of recession as the decreasing number of firms does not have a direct effect on employment. In addition, entrepreneur who do or did business will most probably be more active when looking for a new job. 
R. REDLICHOVÁ, G. CHMELÍKOVÁ, I. BLAŽKOVÁ, V. TAMÁŠ: Role of companies' size in socio-economic...

EKONOMSKI PREGLED, 70 (6) 833-848 (2019)

\section{Acknowledgement}

This contribution was elaborated within the research project FRRMS_ IGA_2018/006: "The Role of Microfinance Sector in the Rural Areas Development”.

\section{References}

Acs, Z. J. (2007): "How is entrepreneurship good for economic growth?", Innovations, 1 (1), 97-107.

Acs, Z.J., Mueller, P. (2008): „Employment effects of business dynamics: Mice, Gazelles and Elephants“, Small Business Economics, 30, 85-100.

Agrawal, A., Cockburn, I., Galasso, A., Oettl, A. (2014): „Why are some regions more innovative than others? The role of small firms in the presence of large labs“. Journal of Urban Economics, 81, 149-165.

Agyapong, D. (2010): „Micro, small and medium enterprises' activities, income level and poverty reduction in Ghana - A synthesis of related literature“, International Journal of Business and Management, 5(12), 196-205.

Arias, M., Atienza, M., Cademartori, J. (2014): "Large mining enterprises and regional development in Chile: between the enclave and cluster", Journal of Economic Geography, 14 (1), 73-95.

Ayyagari, M., Demirgüç-Kunt, A., Maksimovic, V. (2011): "Small vs. Young Firms Across the World: Contribution to Employment, Job Creation, and Growth", World Bank Policy Research Working Paper No. 5631.

Baptista, R., Escária, V., Madruga, P. (2008): „Entrepreneurship, regional development and job creation: the case of Portugal", Small Business Economics, 30, 49-58.

Blažková, I., Chmelíková, G. (2016): „The Influence of Market Concentration on the Development of Newly Born Businesses in the Czech Republic", Acta Universitatis Agriculturae et Silviculturae Mendelianae Brunensis. 64 (3), 929-938.

Boswell, J. (2014): The Rise and Decline of Small Firms (Routledge Revivals), Routledge. London.

Birch,D.G.W.(1979): ,The Job Generation Process“"MIT Program on Neighborhood and Regional Change, 302 
Brown, Ch., Hamilton, J., Medoff, J. (1990): Employers Large and Small, MA: Harvard University Press. Cambridge.

Coughlin, C. C., Segev, E. (2000): "Location determinants of new foreign-owned manufacturing plants", Journal of regional Science, 40(2), 323-351.

Cravo, T. A. (2010): "SMEs and Economic Growth in the Brazilian Micro-regions", Papers in Regional Science, 89 (4), 711-734.

Damborský, M., Wokoun, R. (2010): Location factors of small and medium entrepreneurship under the economic conditions of the Czech Republic, E a M: Ekonomie a Management, 13 (2), 32-43.

De Jorge, J., Suarez, C. (2011): "Influence of R\&D subsidies on efficiency: the case of Spanish manufacturing firms", Cuadernos de Economía y Dirección de la Empresa, 14, 185-193.

Carroll, D. A., Keely J. S. (2009): „Revenue diversification in nonprofit organizations: The answer for longevity?" Journal of Public Administration Research and Theory, 19:947-66.

Constantinides, G. M., Malliaris, A. G. (1995): Portfolio theory. Handbooks in operations research and management science, 9, 1-30.

Florida, R., Mellander, Ch., Stolarick, K. (2008): "Inside the black box of regional development - human capital, the creative class and tolerance", Journal of economic geography, 8(5), 615-649.

Foreman-Peck, J., Tom, N. (2013): "SME Takeovers as a Contributor to Regional Productivity Gaps", Small Business Economics, 41(2), 359-378.

Fritsch, M., Weyh, A. (2006): „How large are the direct employment effects of new businesses? - An empirical investigation“, Small Business Economics, 27, 245-260.

Fritsch, M., Mueller, P. (2008): „The effect of new business formation on regional development over time: the case of Germany“, Small Business Economics, 30, 15-29.

Gilinsky Jr, A., Stanny, E., McCline, R. L., Eyler, R. (2015): „Does size matter? An empirical investigation into the competitive strategies of the small firm", Journal of Small Business Strategy, 12(2), 1-13.

Glasmeier, A. (1988): „Factors Governing the Development of High Tech Industry Agglomerations: A Tale of Three Cities", Regional Studies, 22 (4) 287-301.

Goffee, R., Scase, R. (2015): Corporate Realities (Routledge Revivals): The Dynamics of Large and Small Organisations. Routledge. London.

Grossman, G. M., Helpman, E. (1994): «Endogenous Innovation in the Theory of Growth."Journal of Economic Perspectives, 8(1): 23-44. 
R. REDLICHOVÁ, G. CHMELÍKOVÁ, I. BLAŽKOVÁ, V. TAMÁŠ: Role of companies' size in socio-economic...

EKONOMSKI PREGLED, 70 (6) 833-848 (2019)

Guzmán, J., Lafuente, C., Poza, C. (2014): "Characterization of Business in Terms of Functional Dependence and Productive Dependence: an Application to Six Spanish Regions", Revista De Estudios Regionales, 101, 135-162.

Haltiwanger, J., Jarmin, R. S., Miranda, J. (2013): „Who Creates Jobs? Small versus Large versus Young“, Review of Economics and Statistics, 95 (2), 347-361.

Hansen, N. (1966): „Some Neglected Factors in American Regional Development Policy: The Case of Appalachia“, Land Economics, 42(1), 1-9.

Hansen, N. (1990): "Innovative regional milieux, small firms, and regional development: Evidence from Mediterranean France", The Annals of Regional Science, 24 (2), 107-123.

Haririan, M., Bilgin M. H., Karabulut, G. (2010): “The Relationship between GDP and Unemployment: Evidence from MENA Countries", ZIREB Zagreb International Review of Economics, 13(1), 17-28.

Horell, M., Litan, R. (2010): A_ er Inception: How Enduring is Job Creation by Startups? Working paper: Kauff man Foundation Research Series: Firm Formation and Economic Growth.

Hoselitz, B. (1957):,,Noneconomic Factors in Economic Development“. The American Economic Review, 47(2), 28-41.

Cheng, L. K., Kwan, Y. K. (2000): „What are the determinants of the location of foreign direct investment? The Chinese experience“, Journal of international economics, 51(2), 379-400.

Ibrahim, A. B. (2015): „Strategy Types and Small Firms’ Performance An Empirical Investigation“, Journal of Small Business Strategy, 4(1), 13-22.

Khan, M. A., Saboor, A., Mian, S. A., Anwar, A. (2013): "Modeling the Relationship between GDP and Unemployment for Okun's Law Specific to Pakistan during 1976-2010", Theoretical and Applied Economics, 20 (10), 71-78.

Kane, T. J.(2010): "The Importance of Startups in Job Creation and Job Destruction" (July 2010). Available at SSRN: https://ssrn.com/abstract=1646934 or http:// dx.doi.org/10.2139/ssrn.1646934

Kim, M. J. , Park, S. Y., Jei, S. (2015): “An empirical test for Okun's law using a smooth time-varying parameter approach: evidence from East Asian countries", Applied Economics Letters, 22(10), 788-795.

Kitov, I., Kitov, O. (2012): "Modelling Unemployment and Employment in Advanced Economies: Okun's Law With a Structural Break", Theoretical and Practical Research in Economic Fields (TPREF), 3(1), 26-41.

Kraftová, I. (2008). "Model hodnocení regionů na bázi vicekriteriálního váženého rankingu." proceeding of conference: National and Regional Economics VII. Technical University in Košice (Slovak Republic). 
Kramin, M. V., Safiullin, L. N., Kramin, T. V., Timiryasova, A. V. (2014): „Drivers of economic growth and investment attractiveness of Russian regions", Life Science Journal, 11(6s), 526-530.

Levin, A., Lin Ch.-F., Chu Ch.-S. J. (2002): "Unit root tests in panel data: asymptotic and finite-sample properties." Journal of Econometrics, 108 (1), 2002, pp.1-24

Fisher, M. R.(1961): Towards a Theory of Diversification, Oxford Economic Papers, 13 (3), 1 October 1961, pp. 293-311

Markowitz, H. M. (1999): The early history of portfolio theory: 1600-1960. Financial Analysts Journal, 55(4), 5-16.

Mateo, J. M., Solves , I., M. , Gras, J. M. G. (2013): "Influence of the economic cycle on the determinants of nascent entrepreneurial activity. An empirical analysis of the Spanish case”, Journal of Regional Research Investigaciones Regionales, Special Issue "Entrepreneurial activity and regional development", 26, 19-45.

Moore, B., Tyler, P., Elliott, D. (1991): „The influence of regional development incentives and infrastructure on the location of small and medium sized companies in Europe“, Urban Studies, 28(6), 1001-1026.

Muñoz,F., Trombetta, M. (2015): „Provincial Activity Composite Indicator (IsAP): a contribution to the analysis of Argentine regional economies", Journal of Regional Research Investigaciones Regionales, 33, 71-96.

Nooteboom, B. (1993): „Firm size effects on transaction costs“. Small business economics, 5(4), 283-295.

Ouedraogo, A. (2012): "IT, SME's Performance and Regional Development: An Empirical Study of Insular Firms", Problems and Perspectives in Management, 10(4), 38-48.

Roberts, S. (2014): „The advantages of the supply chain management for small companies“, Demand Media, 1, 1.

Prachowny, M. F. J.. (1993): „Okun's Law: Theoretical Foundations and Revised Estimates." The Review of Economics and Statistics, 75 (2), 1993, pp. 331-336

Pike, A., Rodrígues-Pose, A., Tomaney, J. (2011): Handbook of local and regional development, Routledge. London

Romero, I., Francisco, J. S. (2007): "Firm size and regional linkages: A typology of manufacturing establishments in southern Spain", Regional Studies, 41(5), 571-584.

Sahut, J. M., Peris-Ortiz, M. (2014): „Small business, innovation, and entrepreneurship“. Small Business Economics, 42(4), 663-668. 
Salman, A. K., Shukur, G. (2014): "Investigating Causal Relations between the GDP Cycle and Unemployment: Data from Finland", International Journal of Economics and Finance, 6(4), 118-134.

Samuelson, P. (1975). General Proof that Diversification Pays. Journal of Financial and Quantitative Analysis, 2(1), pp. 1-13.

Savulea, D. (2008): "Particularities of the Correlation between the Unemployment Rate and the GDP in the Dynamics of the Romanian Economy", European Research Studies, 11(4), 111-120.

Solow, R. M. (1956): A Contribution to the Theory of Economic Growth, The Quarterly Journal of Economics, 70 (1), 1 February 1956, pp. 65-94

Ullman, E., L. (1954): “Amenities as a Factor in Regional Growth”, Geographical Review, 44(1), 119-32.

Văduva, L. M. (2008): "Impact of the Entrepreneurial Sector on Regional Development", Annals of the University of Craiova, Economic Sciences Series, 7(36), 3524-3531.

Vandaie, R., Zaheer, A. (2014): „Surviving bear hugs: Firm capability, large partner alliances, and growth“, Strategic Management Journal, 35(4), 566-577.

van Stel, A., Suddle, K (2008): „The impact of new firm formation on regional development in the Netherlands", Small Business Economics, 30, 31-247.

Viturka, M. (2010). Kvalita podnikatelského prostředí, regionální konkurenceschopnost a strategie regionálního rozvoje České republiky, Grada Publishing. Prag.

Wang, L., Liu, Y., Zhou, J. (2010): "The Research on SME and Regional Economic Development: In the Case of Qinglong, Qinhuangdao, Hebei Province", Proceedings of 2010 International Symposium on Economic Development and Engineering Management. 


\title{
ULOGA VELIČINE PODUZEĆA U DRUŠTVENO-EKONOMSKOM RAZVOJU REGIJA U ČEŠKOJ
}

\begin{abstract}
Summary
Cilj ovog rada je istražiti pokretače društveno-ekonomskog razvoja NUTS 3 regija u Češkoj. Cilj se ostvaruje ispitivanjem odnosa jednog od čimbenika regionalnog razvoja - strukture poduzeća i razvoja regije sa socijalnog i ekonomskog stanovišta. Polazimo od teorije diversifikacije i prethodnih empirijskih nalaza te empirijski testiramo ulogu veličine poduzeća u regionalnom razvoju. Koristimo uravnoteženi skup podataka za 14 regija za razdoblje 2000. - 2016. koji pružaju informacije o društveno-ekonomskim rezultatima regija u terminima BDP-a i stope nezaposlenosti. U radu se polazi od hipoteze da je stopa nezaposlenosti u regijama s većim udjelom malih poduzeća manje osjetljiva na opći trend čitavog gospodarstva. Međutim, veći udio malih poduzeća dovodi do poboljšanog regionalnog BDP-a. Dobiveni rezultati potvrđuju da mala poduzeća ubrzavaju gospodarski rast istovremeno igrajući ulogu socijalnog stabilizatora u češkim regijama. Dobiveni zaključci mogli bi pomoći u osmišljavanju regionalne politike u Češkoj.

Ključne riječi: Prosječna plaća, diversifikacija, BDP, regionalni razvoj, veličina poduzeća, nezaposlenost
\end{abstract}

